\title{
Primary and Lower Secondary School Teachers: Teachers' Attitudes and Perceptions about Traditional Teaching Methodologies and Modern Teaching Methodologies according to RWCT
}

\author{
Xhevahire Karanezi \\ University of Tirana, Tirana, Albania \\ Email: xhevahirekaranezi@gmail.com
}

Received 1 August 2014; revised 20 August 2014; accepted 26 August 2014

Copyright (C) 2014 by author and Scientific Research Publishing Inc.

This work is licensed under the Creative Commons Attribution International License (CC BY). http://creativecommons.org/licenses/by/4.0/

c) (i) Open Access

\begin{abstract}
Reading and Writing for Critical Thinking (RWCT) is a modern teaching philosophy which is based on the philosophy of constructivism, according to which the students actively participate in building up knowledge through involvement in research activities (Kosova Education Center, 2011). Aim of the investigation: The aim of the study was to investigate the differences between attitudes and perceptions of the teachers of primary and lower secondary schools in regard to a traditional and modern teaching methodology such as RWCT. Method: This is a quantitative and a qualitative study. Questionnaires were utilized for the quantitative data collection, whereas a focus group discussion was conducted for qualitative data collection. The study was implemented in a sample of 473 9th grade school teachers in Kosovo. The sample was selected using a random sample selection with inclusion of urban and rural areas proportionally. Results: The data suggest there is a significant difference in attitudes and perception of primary and lower secondary school teachers, in all three measured scales: attitudes about traditional methodologies $(t=2.358, p=.019)$; attitudes about modern methodologies as RWCT $(t=3.077, p=.002)$ as well as teachers' perception about the teaching process $(t=2.981, p=.003)$. Differences in primary and lower secondary school teachers' attitudes and perception were also reflected in the qualitative data findings. Conclusion: Based on the quantitative and qualitative data, it can be noted that there is a significant difference in primary and lower secondary school teachers' attitudes and perceptions towards teaching methodologies.
\end{abstract}

\section{Keywords}

RWCT, Attitudes, Perceptions, Traditional Teaching, Modern Teaching 


\section{Introduction}

Nowadays, the school is presenting an institution where reproduction and possession of information is no longer required. If the teaching process does not encourage students to think effectively, students will fail to accomplish the main teaching aim and objectives to become an active part of the society and be able to face daily challenges. Therefore, nowadays the mission of the school is to better prepare new generations who are able to search for the information, to research, to operate, analyze and to solve problems in a critical manner (Kosovo Pedagogical Institute, 2008). A critical thinker is not necessarily a person who has a good memory or knows a lot of facts. In contrary, a critical thinker is able to deduce consequences from what he/she knows, and he/she is able to seek and use relevant sources of information in order to inform himself/herself as well as solve problems (Lau, J, \& Chan, J., 2004-2014). Traditional teaching methodologies with teacher in the centre were not anymore applicable considering the new changes and daily challenges that the society was facing. Hence, the new teaching methodologies with the student in the centre are being implemented all over the world, by continuously promoting critical thinking. A training program, the Reading and Writing for Critical Thinking (RWCT) is more than an attempt to replace traditional methods with innovative techniques (While \& Ulqini, 2003). Based on the constructivism, which transforms the students from a passive recipient of information to an active participant in the learning process, the RWCT program provides teachers with specific strategies for interactive methods of teaching that helps them to prepare students to become active citizens in an open society (American Institutes for Research, 2001). In the constructivist classroom, the focus shifts from the teacher to the students, so the constructivist teacher provides tools for students, which helps them to formulate and test their ideas, draw conclusions and convey their knowledge in a collaborative learning environment (Educational Broadcasting Corporation, 2004). Always being guided by the teacher, in the RWCT classrooms students construct their knowledge actively instead of just mechanically taking them from the teacher or the textbook. At the heart of the RWCT program is its pedagogical framework that describes three aspects involved in learning-Evocation, Realization of Meaning and Reflection-ERR (While \& Ulqini, 2003). ERR structure begins with the stage Evocation in which the teacher connects the content of the new information for students with their previous knowledge. Then, this goes on the stage Realization of Meaning when the students deal with research, review and learning of content. In the last stage Reflection they discuss and reflect on what they have learned by interpreting the material or using it to solve problems. In general, RWCT is a project which enables teachers to sustain the values created through education and experience by enriching them with new knowledge which is required for their professional needs. Teachers report that they have noted ways in which their personal career has benefitted from their participation in this program (Covacs \& Cretu 2010). Hence, increasing teacher involvement in this program enables us to preserve their interest in continuous professional development and the greatest beneficiaries would be our students and our future.

\section{Literature Review}

According to Richards (2008) traditional methodology was explained as learning that was very much seen as under the control of the teacher. In this regard the traditional classrooms were seen like ceremonial places where students sat in rows like spectators, while the teacher sat in front of them as a mayor or a priest (Crawford et al., 2005). Unlike traditional methodology, modern methodology is much more student-centred. Scrivener (2005) explains that in modern methodology the main role of the teacher is to help students in the process of learning by encouraging, involving and helping them to try out and explore. As a unlike project, RWCT brought together teachers of all educational levels and the faculty in order to actively discuss about all the necessary changes in the teaching methodologies by considering teacher's role as a crucial factor in this change (Steele, 2001). It goes almost without saying that in order to be able to develop different skills in others; teachers need to be themselves skilled before. Without doubt, this is the case for critical thinking (Kennedy et al., 1991). For that reason, it was suggested that specific courses have to be designed in order to train teachers on using different teaching methods, as well as compile adequate books and materials about teaching critical thinking. These teaching methods are designed to help students think in a reflective way, learn independently, understand the logic of the arguments and become a long life learner (Critical Thinking International, 2007-2013). As a modern methodology, RWCT program in Kosovo started in October 2000 under the auspices of the Kosovo Education Centre (KEC), one of the most active NGOs recognized in the field of education (Pupovci \& Taylor, 2003). In the last decade, RWCT 
was one of the largest educational development program, with outstandingly high popularity, which reached out almost one fourth of all teachers in Kosovo (Rado, 2013).

One should be noted that teaching methods used by teachers, are also influence by their attitudes and perceptions. According to Schoenfeld (1992) attitudes and perceptions influence teachers not only how, but what, he or she teaches. As such, teachers' attitudes and perceptions impact their style of teaching, selected resources, as well as establishment of their classrooms. Furthermore, Munby (1982) created a cycle of issues that influence the teachers' instructional methods used, from which resulted the teachers' characteristics and cognitive processes were at the heart of the cycle. Barnyak and Paquette (2010) stated that even though some of the teachers learn about new teaching methods, they still use their own strategies and methods that are more convenient for them. Similarly, Leach and Moon (1999) illustrate that teachers have always tried to adapt their teaching based on the backgrounds, abilities, styles and interests of the learners. However, they also bring their own beliefs and assumptions to the classroom (Leach and Moon, 1999). As Rado (2013) explains, an indicator of a possible change of the teaching is the extent to which the teacher shows an optimistic attitude towards the possible impact of good teaching. He point out that one of the typical symptoms of teachers' frustration is responsibility shift. In addition, participation in a 120 hours training, which RWCT program provides, rarely causes deep cognitive and attitudinal changes (Rado, 2013). In a study conducted with Kosovar teachers, it was found that there were minor differences on the impact of RWCT trainings between teachers' of primary and lower secondary schools (Rado, 2013). According to this study, it was also found that primary school teachers showed more optimistic view of potential teaching. These teachers were doing less lecturing, and they were encouraging more open discussions compare to teachers of lower secondary schools. The study also pointed out that primary schools teachers provided more waiting time for students' response comparing to teachers of lower secondary schools (Rado, 2013). It should also be noted that, teachers of secondary schools found RWCT techniques more different from the way and methods that they taught earlier, and they usually, apply those RWCT methods that do not require movement in the classrooms (Rado, 2013).

It is important to note that, the RWCT program is based on the theory that changing teaching practices is not an easy thing. Changes in the teaching process need time. The teachers needs time to understand, feel, try and plan new methodologies with their students. Both students and teachers need more time to get familiar with the new learning methods and methodologies (Temple et al., 2006).

\section{Methodology}

This study was conducted using quantitative and qualitative data collection methods. In total, 473 school teachers from different regions of Kosovo participated in this research study. The quantitative data were collected utilizing questionnaires which were compiled and adjusted in accordance with the study objectives.

According to Krueger (1998) focus group discussions helps to explore and understand more the specific issues, going into a deeper level then quantitative methods. It is important to be noted that according to Krueger and Casery (2000) focus group discussions helps the researchers to understand much better and in a deeper level specifically participants' perception, thoughts and feelings in regard to the specific issues. Hence, in order to obtain in depth information and to better understand teachers' perceptions and attitudes toward traditional versus modern teaching methodologies, 4 focus group discussions were conducted with school teachers' of primary and lower secondary school in Kosovo. The focus group participants were selected with respect to level on which they are working in, as well as urban and rural area.

\section{Participants}

Primary school teachers of grades 1 to 9 participated in this research study. From the total of 473 school teachers who participated in this study 219 of teachers were of primary school (grade 1 - 5) and 254 of them were teachers of lower secondary school (grade 6 - 9). Teachers from 23 primary schools in Kosovo participated in this study. The study was conducted in 6 different regions with respect to urban and rural stratification. The data were collected in schools premises and the questionnaires were administrated by the research team.

Same as for the qualitative data collection, school premises were used to conduct the focus group discussions. The focus group discussions were comprised of 6 to 8 participants. Prior to each focus group discussions, the participants were asked to sign a consent form for participation in the focus group discussion. 


\section{Instruments}

A specific questionnaire was compiled in order to be used for the quantitative data collection. The questionnaire was developed in accordance with the study objectives and some of the questions were adapted by the questionnaire, which was used by Pupovci and Taylor, 2003 for one of the studies conducted with Kosovar teachers previously.

Prior to the data collection, a pilot study was conducted for testing the questionnaire. The pilot was conducted with teachers from two primary schools which were not selected for the main data collection. During the pilot study, teachers were asked to fill in a questionnaire and after that were invited for an open discussion and give their feedback about the questions and the questionnaire in general. The pilot resulted with the modification of few questions and there were no questions recommended to be added or removed. The teachers declared that the questions were clear enough, comprehensive, and had a logical flow. All teachers' recommendations were integrated in the final version of the questionnaire which was used for the main data collection.

\section{Procedure of Data Collection}

The questionnaires were administrated to the teachers in the school premises where teachers were working. In order to ensure privacy and enough space for each participant, the questionnaires were administrated in different rounds in small groups of teachers. During the entire process of the data collection, teachers were informed and encouraged to ask for anything that might have been not clear to them.

The focus group discussions were also conducted in school premises with 6 to 8 participants and were conducted after teachers' official working hours. The focus group discussions were conducted in a separate physical space where nobody apart the research team had access. Before starting with the focus group discussion, the participants of each focus group were first informed about the flow of the discussion, their right to withdraw and were strongly encouraged to actively participate and contribute to the discussion. The participants were asked for permission in order for the focus groups discussion to be recorded.

\section{Results}

Teachers who participated in this research study were selected with respect to the school levels on which they are working.

The Figure 1 shows the percentage of teachers who participated in the study by the level of schools in which they are working. As presented in the figure, 46.3\% $(\mathrm{N}=219)$ of the participants where teachers working in the primary schools ( 1 - 5 grades) and $53.7 \%(\mathrm{~N}=254)$ in lower secondary schools ( 6 - 9 grades).

The data presented in the Table 1 show the differences between teachers' attitudes toward traditional and modern teaching methodologies and teachers' perceptions for the teaching process considering the schools in which they are working. The data shows that there is a significant difference between teachers of primary schools (1 - 5) and lower secondary schools (6 - 9) and their attitudes and perceptions.

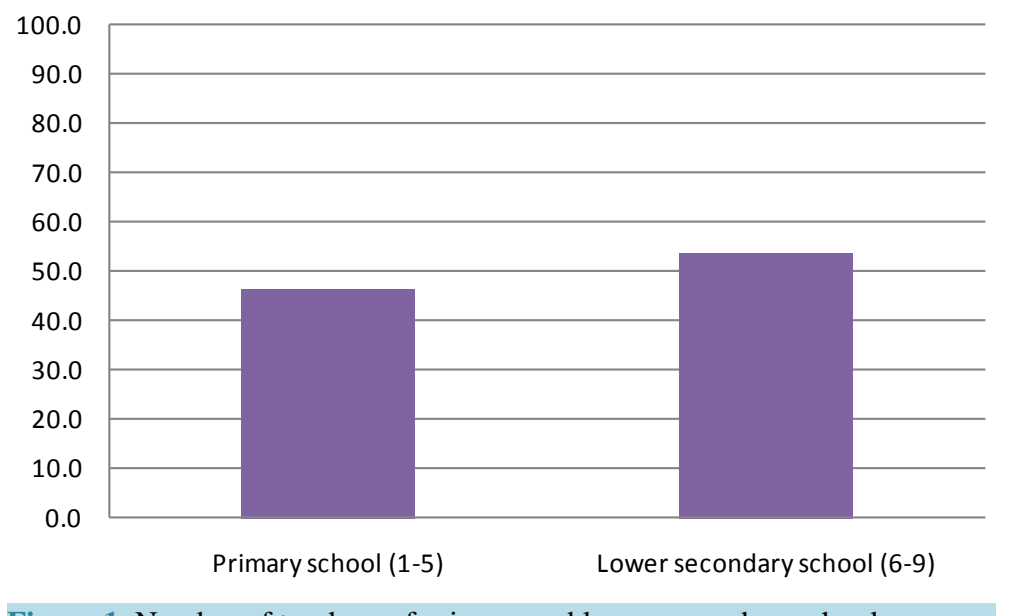

Figure 1. Number of teachers of primary and lower secondary school. 
Table 1. Teachers' attitudes and perceptions by the level of schools in which they are working.

\begin{tabular}{|c|c|c|c|c|c|}
\hline & & Mean & Std. Deviation & Std. Error Mean & Sig. \\
\hline \multirow{2}{*}{$\begin{array}{l}\text { Attitudes toward traditional teaching } \\
\text { methodologies }\end{array}$} & Primary school (1 - 5) & 13.7854 & 3.98098 & .26901 & .019 \\
\hline & Lower secondary (6 - 9) & 12.9646 & 3.58889 & .22519 & \\
\hline \multirow{2}{*}{ Attitudes toward RWCT } & Primary school (1 - 5) & 47.9680 & 9.42103 & 63661 & .002 \\
\hline & Lower secondary (6 - 9) & 45.5354 & 7.77021 & .48755 & \\
\hline \multirow{2}{*}{$\begin{array}{l}\text { Teachers perceptions toward the } \\
\text { teaching process }\end{array}$} & Primary school (1 - 5) & 48.4292 & 5.74203 & .38801 & .003 \\
\hline & Lower secondary (6 - 9) & 46.8780 & 5.55576 & .34860 & \\
\hline
\end{tabular}

As presented in the Table 1, there is a significant difference between teachers of primary and lower secondary schools and their attitudes toward traditional teaching methodologies $(\mathrm{t}=2.358, p=.019)$, attitudes toward RWCT ( $\mathrm{t}=3.077, p=.002)$ as well as their perceptions toward the teaching process in general.

It should be noted that teachers from primary schools $(1-5)$ scored significantly higher in all three scales measured. The level of significance was much higher for attitudes toward RWCT and perceptions toward teaching process.

\section{Findings from Focus Group Discussions}

When looking at the qualitative data it can be noted that teachers of primary schools and those of lower secondary schools declare different attitudes and perceptions toward the teaching methodologies and teaching process in general. In general, the qualitative data shows that teachers of primary schools are more open toward modern teaching methodologies and presents with more negative attitudes toward traditional teaching techniques compare to teachers of lower secondary schools. According to the teachers of lower secondary schools modern methodologies are not applicable and/or very difficult to apply with students of higher grades (6 to 9).

Participant 1-Teacher of primary school (1 - 5) "RWCT teaching methods are very helpful and easy to apply. Through these teaching methods students learn easier and faster, and teacher can learn also a lot about their students. More importantly these methods are very lovely for children. I would say that there are times when traditional teaching technique are necessary and important, but it is sure that traditional techniques do not make the students part of the learning process at all, they are very passive in the whole teaching process".

Participant 2-Teacher of primary school $(1$ - 5) "Through RWCT teaching methods students are able to learn and think in a better way. RWCT methods contribute a lot to students' critical thinking. I think this is the difference when comparing these techniques with the traditional teaching techniques, since traditional teaching techniques keeps the students more closed and not unable them to think in a critical way".

Participant 3-Teacher of lower secondary school (6 - 9) "It is much more difficult to apply RWCT techniques with students of 8 grades. How are they supposed to learn physics or chemistry using such techniques? I think that traditional techniques are more applicable for students of this age, these methods are more straight forward and more applicable considering the subjects of these school levels?"

Participant 4-Teacher of lower secondary school (6 - 9) "I agree, it is difficult with students of higher grades 6, 7 and up... It is more difficult to control them, specifically considering the higher number of students in a classroom. Traditional methods keeps the students more in order, these techniques are more applicable for the subjects of these school levels".

In regard to teachers' perceptions, the findings from qualitative data shows that in general teachers of primary schools (1 - 5) showed more positive perceptions toward teaching process compare to teachers of lower secondary schools (6 - 9).

Participant 1-Teacher of primary school (1 - 5) "I teach the same students for 5 years, even though we have high number of students in the same classroom, it is important for me that I am responsible only for them, and I am very independent on working with them".

Participant 1-Teacher of lower secondary school (6 - 9) "For me it is very difficult as I have to teach students of more than 10 different classrooms... this is a huge number of students and sometimes is even difficult to know all of them". 


\section{Discussion}

The aim of this study was to investigate the differences between teachers of primary and lower secondary schools and their attitudes and perceptions in regard to a traditional and modern teaching methodology such as RWCT. In order to better measure and understand teachers' attitudes and perceptions quantitative and qualitative data were collected. Both findings showed that there were differences between teachers' attitudes and perceptions of primary and those of lower secondary schools. The data resulted with significant differences between teachers of primary and those of lower secondary schools and their attitudes toward traditional teaching methodology. Surprisingly, teachers' of primary schools declared more positive attitudes toward traditional teaching methodology, even though the difference was not very strong but significant. Contrary, based on the findings from the focus group discussions, teachers' of primary school showed more negative attitudes toward traditional techniques compare to the teachers' of lower secondary school, even though some of teachers declared that there are times when they apply traditional techniques. The findings of this study can also be explained by the findings from another study conducted with teachers in Kosovo, in which the study resulted with minor differences between teachers' of primary and lower secondary schools in regard to RWCT training impact (Rado, 2013). The data resulted with strong significant differences between teachers' of primary and lower secondary schools and their attitudes toward RWCT. Teachers of primary schools showed more positive attitudes toward RWCT compared to teachers' of lower secondary schools. The findings were in the same line with the qualitative data collected through focus group discussion. Teachers of primary schools declared more positive attitudes toward RWCT compared to teachers of lower secondary schools who declared that RWCT is not very applicable for students of higher grades. Another study conducted with teachers in Kosovo showed that teachers' of lower secondary school compared to those of primary schools, find RWCT techniques more different compare to what they were taught (Rado, 2013).

Furthermore, the data showed that there was a significant difference between teachers of primary and lower secondary school and their perceptions toward teaching process. Teachers of primary school showed more positive perceptions toward teaching process compared to teachers of lower secondary school. Moreover, qualitative data revealed with the same findings where teachers of primary and lower secondary school share different perceptions toward the teaching process. Based on the findings showed by the focus group discussions, teachers of lower secondary schools declared that the teaching process is more challenging for them in general. Some of the challenges raised by teachers of lower secondary schools were higher number of students, teaching different students from different grades etc.

\section{Conclusion}

Based on the quantitative and qualitative findings, it can be concluded that the data resulted with significant differences between attitudes and perception among teachers of primary and those of lower secondary schools. The data resulted with significant differences in attitudes toward RWCT and perception about teaching process among teachers of primary and lower secondary schools. As the data showed, primary school teachers reported with more accepting attitudes toward RWCT as well as more positive perceptions about teaching process in general compare to the teachers of lower secondary school. One should be noted that teachers of primary schools declared more positive attitudes toward traditional teaching methodology, which was not in the same line with findings from the focus group discussions. A further investigation of attitudes about traditional teaching methodology among these two groups of teachers would be of great interest. It is important to be noted that, the findings are in the same line with the findings from the qualitative data where primary school teachers declared more accepting attitudes toward RWCT as well as more positive perceptions toward the teaching process in general compared to the teachers of lower secondary school.

\section{References}

American Institute for Research (2001). The 2000-2001 Reading and Writing for Critical Thinking Project Impact and Institutionalization Study. New York: OSI.

Barnyak, N. C., \& Paquette, K. (2010). An Investigation of Elementary Preservice Teachers Reading Instruction Beliefs. Reading Improvement. Farmington Hills, MI: Gale Group.

Covac, M., \& Cretu, N. (2010). Critical Thinking Program Review. OSI. 
Crawford, A., Saul, W., Mathews, S., \& Makinster, J. (2005). Teaching and Learning Strategies for the Thinking Classrooms. The International Debate Education Association.

Educational Broadcasting Corporation (2004). Constructivism as a Paradigm for Teaching and Learning (30th ed.). Online.

Kennedy, M., Fisher, M. B., \& Ennis, R. H. (1991). Critical Thinking: Literature Review and Needed Research. In L. Idol, \& B. P. Jones (Eds.). Educational Values and Cognitive Instruction: Implications for Reform, Hillsdale, NJ: Lawrence Erlbaum.

Kosova Education Center (2011). Working Report 2010. Prishtinë.

Kosovo Pedagogical Institute (2008). The Impact of Teaching Training in Education Process. Prishtinë.

Krueger, R. A. (1998). Moderating Focus Groups. Thousand Oaks, CA: Sage Publications.

Krueger, R., \& Casey, M. (2000). Focus Groups. A Practical Guide for Applied Research (3rd ed.). Thousand Oaks: Sage Publications.

Lau, J., \& Chan, J. (2004-2014). What Is Critical Thinking?

Leach, J., \& Moon, B. (1999). Learners and Pedagogy. Thousand Oaks: Sage Publication.

Munby, H. (1982). The Place of Teachers’ Beliefs in Research on Teacher Thinking and Decision Making, and an Alternative Methodology. The Annual Meeting of the Southwest Educational Research Association, Austin, 11-13 February 1982, 201-205.

Pupovci, D., \& Taylor, A. (2003). Reading and Writing for Critical Thinking. Final Evaluation Report. Prishtinë: Kosova Education Centre.

Rado, P. (2013). The Evaluation of the Reading and Writing for Critical Thinking Program in Kosovo. Final Evaluation Report. Prishtinë: Kosova Education Center.

Richards, J. C. (2008). Communicative Language Teaching Today. New York: Cambridge University Press.

Schoenfeld, A. H. (1992). Learning to Think Mathematically: Problem Solving, Metacognition, and Sense-Making in Mathematics. In D. Grouws (Ed.), Handbook for Research on Mathematics Teaching and Learning (pp. 334-370). New York: MacMillan.

Scrivener, J. (2005). Learning Teaching. Oxford: MacMillan.

Steele, J. L. (2001). The Reading and Writing for Critical Thinking Project: A Framework for School Change. In D. Klooster, J. Steele, \& P. Bloem (Eds.), Ideas without Boundaries: International Educational Reform through Reading, Writing and Critical Thinking (pp. 2-21). Newark, DE: International Reading Association.

Temple, C., Crawford, A., Saul, W., Mathews, S., \& Makinster, J. (2006). Teaching and Learning Strategies for the Thinking Classroom. Trainers Guide. New York: The International Debate Education Association.

Wile, M. J., \& Ulqini, L. (2003). Developing Critical Thinking Skills in Eastern Europe. Paper Presented at the World Bank's International Workshop, Curricula, Textbooks, and Pedagogical Practices and the Promotion of Peace and Respect for Diversity, Washington, D.C., 24-25 March 2003. 


\section{Appendixes}

Sample of questions used for the focus group discussions:

1. Are you familiar with RWCT or critical thinking strategies?

2. Where did you get this information?

3. What does critical thinking means for you?

4. Have you ever attend a RWCT training? If no, what is the reason for not attending this training?

5. Do you apply any of the RWCT methods during your daily work with students. If yes, please expalin? If no, please explain?

Frequency tables presenting frequencies of some of the questions used in the questionnaire:

\begin{tabular}{ccc}
\hline \multicolumn{2}{|c|}{ Where did you learn about RWCT teaching methodology? } \\
\hline & Frequency & Valid Percent \\
\hline I have read about it & 99 & 57.6 \\
From colleagues & 60 & 34.9 \\
Other & 13 & 7.6 \\
Total & 172 & 100.0
\end{tabular}

Have you ever practice critical thinking techniques in your classroom?

$\begin{array}{ccc} & \text { Frequency } & \text { Valid Percent } \\ \text { Yes } & 426 & 90.1 \\ \text { No } & 47 & 9.9 \\ \text { Total } & 473 & 100.0\end{array}$

Traditional methodology is more successful compare to modern methodology.

$\begin{array}{ccc} & \text { Frequency } & \text { Valid Percent } \\ \text { Totally disagree } & 43 & 9.1 \\ \text { Somewhat disagree } & 163 & 34.5 \\ \text { Don't know } & 12 & 2.5 \\ \text { Somewhat agree } & 111 & 23.5 \\ \text { Totally agree } & 144 & 30.4 \\ \text { Total } & 473 & 100.0 \\ \text { Traditional teaching methodology is boring for students. } & \\ \text { Trequency } & \text { Valid Percent } \\ \text { Totally disagree } & 73 & 15.4 \\ \text { Somewhat disagree } & 98 & 20.7 \\ \text { Don't know } & 30 & 6.3 \\ \text { Somewhat agree } & 144 & 30.4 \\ \text { Totally agree } & 128 & 27.1 \\ \text { Total } & 473 & 100.0\end{array}$

The work I am doing it meets my expectations that I have previously had for the teaching process.

$\begin{array}{ccc} & \text { Frequency } & \text { Valid Percent } \\ \text { Totally disagree } & 15 & 3.2 \\ \text { Somewhat disagree } & 18 & 3.8 \\ \text { Don't know } & 19 & 4.0 \\ \text { Somewhat agree } & 166 & 35.1 \\ \text { Totally agree } & 255 & 53.9 \\ \text { Total } & 473 & 100.0\end{array}$




\section{Continued}

I have enough autonomy to decide in my own on which teaching strategies to use in my daily work.

\begin{tabular}{ccc} 
& Frequency & Valid Percent \\
\hline Totally disagree & 21 & 4.4 \\
Somewhat disagree & 22 & 4.7 \\
Don't know & 15 & 3.2 \\
Somewhat agree & 104 & 22.0 \\
Totally agree & 311 & 65.8 \\
Total & 473 & 100.0 \\
\hline
\end{tabular}


Scientific Research Publishing (SCIRP) is one of the largest Open Access journal publishers. It is currently publishing more than 200 open access, online, peer-reviewed journals covering a wide range of academic disciplines. SCIRP serves the worldwide academic communities and contributes to the progress and application of science with its publication.

Other selected journals from SCIRP are listed as below. Submit your manuscript to us via either submit@scirp.org or Online Submission Portal.
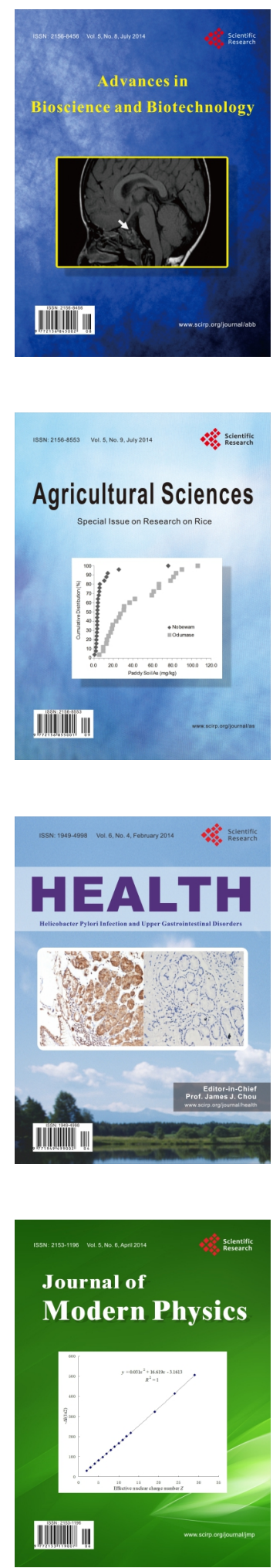
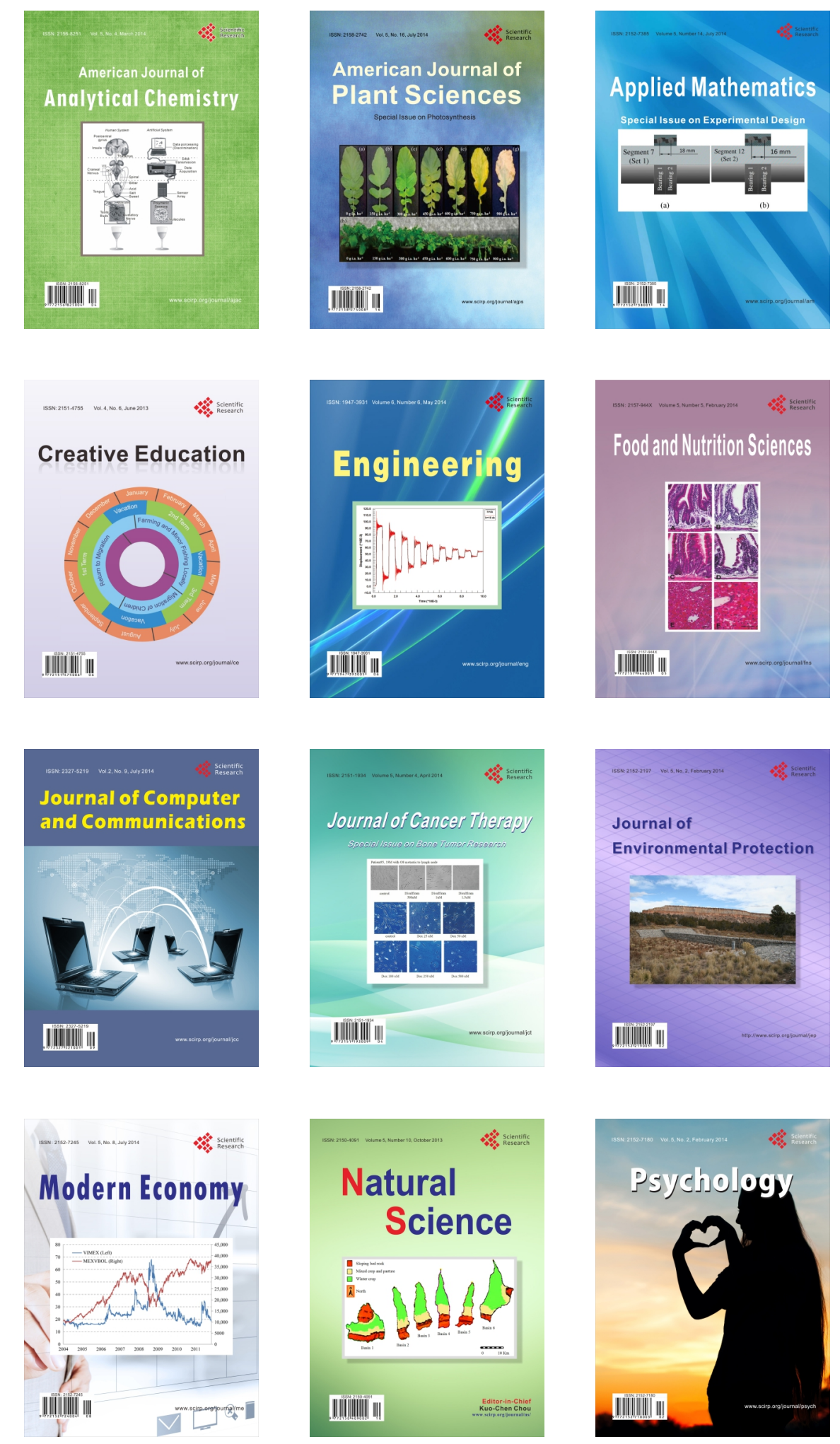